\title{
The Occupy and Indignados movement and the importance of political context: differences between occasionals and regulars in Spain and the UK
}

Cristina Gomez-Roman, Universidade de Santiago de Compostela

Jose Manuel Sabucedo, Universidade de Santiago de Compostela

\begin{abstract}
In this work we look into the individuals' reasons that led Occupy protesters to participate in this movement. We interviewed Occupy participants in the UK and Spain. We wanted to find out if the reasons that lead them to participate are the same in both countries. The context of the country where the demonstration was held was taken into account, as well as the differences there may be in the reasons for participation if we consider whether they are occasional or regular participants in collective protest actions. Using a two-by-two design defined by country of demonstration and the history of mobilisation (occasional vs. regular), our results show important differences in both factors. The study contributes to the literature, highlighting the importance of analysing the context where the demonstration takes place and which motives must be underlined in order to attract participants to protests.
\end{abstract}

\section{Keywords}

Political context; participation motives; Occupy; Spain; UK.

\section{JEL classification}

D74; D83; E65. 
In May 2011, thousands of people throughout Spain, outraged by socio-economic prospects and the lack of political responsibility, organised marches and protests in 58 different cities (Feixa, 2013). Beginning in Madrid and spreading quickly throughout the country, protesters took over squares and set up encampments, some lasting for weeks. In these camps, participants debated and managed the occupation through general assemblies and various issue-specific working groups. On 15 October 2011, a similar scene played out next to St Paul's Cathedral in London, where a group of activists met and began an occupation, which lasted until 14 June 2012. Inspired by the camps in Spain, participants debated and managed the occupation through general assemblies and smaller commissions, streaming their protests live on social media.

Participants of both countries have been referred to as the Indignados and Occupy movement, respectively. These movements do not arise in a vacuum; their appearance was inspired by the global protest wave that started in Tunisia, later spread across North Africa and the Middle East, in what was called the Arab Spring (Costanza-Chock, 2012; Gledhill, 2012; Tejerina, Perugorría, Benski, \& Langman, 2013). These protests were also related to the political-economic crisis taking place in Europe (Halvorsen, 2012), and as a result of dissatisfaction with the global crisis and the inefficient decisions by governments in responding to it. They rejected "politics as usual," demanding a more equal and transparent financial/economic system (Democracia Real Ya, 2014; Occupy London, 2014).

These movements were the beginning of a wave of protests that took place in 2011-2012 resulting in what is known as a new cycle of protest (Tarrow, 1991). These movements were able to expand a discourse fitting with the general feeling of indignation. They were not claiming for specific issues (for instance: rejecting labour reform, demonstrating against abortion or climate change), but demanding a radical change in applying democracy, a radical change of the political system itself (van Stekelenburg, 2012; Langman, 2013).

In addition, the Spanish and British examples had a contagion effect on other countries: the USA, Turkey, the Netherlands, among others, all subsequently started their own similar movements. The squares in several international cities were also similarly occupied, according to van Stekelenburg (2012: 224): 'In February 2012, there were squares occupied in 1590 cities worldwide.' This movement was a convergence of tactics and ideas, not novel on their own, but which, when combined, were able to energise activism that hadn't been seen for several years, attracting not only media attention but the interest of many academics worldwide (Pickerill \& Krinsky, 2012). A similar movement occurring in several countries provides a unique opportunity for academic study.

Previous research in the Occupy/Indignados movement has studied this protest related to its particular organisational structure (Manilov, 2013), or has executed single case studies in different regions of Occupy demonstrations (monographic in Social Movement Studies, 2012; Pickerill \& Krinsky, 2012; Howard \& Pratt-Boyden, 2013; Halvorsen, 2015). However, these studies didn't make comparisons in order to establish if participants in the protest have the same motives to participate. The analysis of political protests, and more specifically the Occupy/Indignados movement, cannot be carried out in isolation, studying one single action. As Klandermans and Smith (2002: 6) pointed out, 'comparative research of movement participation is important. It tells us that what holds for a participant in one movement, or at one point in time, or in one place is not necessarily true for a participant in another movement, or at a different time or place'. In this case, comparing the same movement in two countries, we can examine how variations result from differences in the context in which the protest takes place, and how they interact with these contexts, increasing our knowledge in the general dynamics of protests. 
In this work we are interested in establishing the individual reasons leading protesters to participate in the actions of the Indignados and Occupy movement: What has led them to take part in the protests? In order to do so, we have interviewed Occupy participants in the UK and Spain. We wanted to find out if the reasons that lead them to participate are the same in both countries and if there are differences among them. We take into account the context of the country where the demonstration was held, and also the differences there may be in the reasons to participate, differentiating whether they are occasional or regular participants in collective protest actions. In line with recent work (Verlhust \& Walgrave, 2009; Saunders, Grasso, Olcese, Rainsford, \& Rootes, 2012; Rüdig \& Karyotis, 2013), we understand that even within the same demonstration different profiles of protester may exist: those who have been taking part in protest all their lives (regulars) and those who, due to crisis circumstances and the appearance of a new movement (far from standard political parties or trade unions), are occasionals (those who don't have a long tradition of participation).

\section{Context that matters: Country where the demonstration takes place.}

Although the assumption that the increase in the number of people who claim to have taken part in protests in recent decades has not been without controversy (Biggs, 2014), the fact is in recent years there has been objective data showing a considerable increase in the number of demonstrations (ESS, in Jiménez, 2011; Thomas \& Louis, 2013). This increase in the number of protests has probably been due to the effect of the economic crisis and citizens' disenchantment with the policies undertaken to respond to it. Dissatisfaction with democracy and poor trust in governments and politicians appears to be important in the participation of citizens (Gómez-Román \& Sabucedo, 2014).

Our approach assumes that in protest dynamics we need to consider the political context, that is, the perception and interpretation people hold on the political environment where they are embedded. We need to take into consideration these perceptions of the political context to understand the differences between participants. Depending on these interpretations, they will activate different motivations encouraging individual participation. The context will have a bearing on the profile of the participant and on motivations for participation. Social movements have a crucial role in creating discourses fitting with these perceptions. They must be able to frame the situation in an attractive way so as to bring as many people possible to demonstrations.

One of the first attempts to study the complex relationship between protest and context was a longitudinal study of four centuries of action repertoires in France, by Charles Tilly (1986), who demonstrated that the repertoires of action changed according to an evolving context. Another more recent attempt to study this relationship between protest and context was a comparative study by Walgrave and Rucht (2010). They formulated the term 'issue-specific context' to refer to the interactions between national context and the issue(s) of the demonstration. The authors' evidence stems from the demonstrations against the war in Iraq. In their study, the issue of the demonstration was the same in each of the countries but the national context differed considerably. The authors showed that the composition of the crowd varied depending on this contextual variation. In a more recent work, Klandermans, van Stekelenburg, Damen, van Leeuwen and van Troost (2014) observed that at least the actors on stage may vary considerably as a result of the contextual setting in which they are staged. They found that the national context within which these demonstrations are taking place added information to the scene; furthermore they observed consistent differences due to this contextual variation. 
In this work, we compare two Occupy demonstrations in two countries of Europe: Spain and the UK. These countries are similar because the crisis hit both hard and the two have traditionally low trust in government. The UK and Spain have become more indebted as a result of the Great Bailout and according to McNally (2010) public debt in these countries is now above 60 per cent. Both countries have had to take austerity measures to confront this difficult situation. For instance, in Spain, among other austerity measures, the socialist government included an increase in higher rate income tax and 8 per cent spending cuts, public sector workers have had their pay cut by 5 per cent and salaries frozen, and the retirement age was raised to 67. In the same line, in the UK, the Conservative-Liberal Democrat Coalition government took the biggest cuts in state spending since the Second World War, as well as increasing the retirement age to 66 , cutting 490,000 public sector jobs, and making budget cuts of 19 per cent on average up to 25 per cent in most government departments (Farnsworth \& Irving, 2012). The situation in Spain was clearly worse at that time: the level of unemployment was at that time 22.85 per cent, twice the average of the European Union (INE, 2012; EUROSTAT, 2012); while the UK's unemployment was the worst in the country since 1994, it was only around 2.62 million (8.2 per cent). The Spanish economy was also in the European Union's spotlight, as they decided on the necessity of a bailout plan. Alongside the economic crisis in Spain, there was also a political crisis taking place. Politicians were identified as the third most important problem in Spain, following unemployment and the economic crisis (Anduiza, Cristancho, \& Sabucedo, 2013).

As for the influence of the adversity of the national setting, we presume that in Spain, the perceptions of the political context underlying movement claims would influence motivations to participate in Occupy demonstrations.

\section{Different participants at the same demonstration: Occasionals and regulars}

According to the European Social Survey, the number of people claiming to have participated in a demonstration in the past 12 months has increased between 2008 and 2012 (ESS, 2012). This increase in the number of protests and the people who claim to have participated in it, are indicators that during the crisis period a large number of people who have not previously participated regularly may have been mobilised. The unfavourable political and economic environment and the appearance of a movement far from usual mobilisation agents (trade unions or political parties) encouraged the participation of citizens who were previously outside of politics. Therefore, in this particular political and economic context, it is very important to study those who are participating not only in general terms, but to find out if their motives are the same for the occasionals (or sporadic participants) and the regulars (those who have been participating regularly). We strongly believe those who only participate occasionally in these times of crisis were not in the demonstration for the same reasons as the usual protesters. We understand that the economic and political context of hardship and the emergence of a movement like Occupy have made the protest more attractive to those citizens who are not regular activists.

While it is true that in recent years there has been a large number of empirical studies explaining the general causes of protest behaviour (van Zomeren, Postmes \& Spears, 2008; Dalton, van Sickle, \& Weldon, 2009; van Stekelenburg \& Klandermans, 2010), the fact is there are still few works dealing with the existence of multiple profiles of protester within the same protest. In one of these studies, Saunders et al. (2012), the authors classify four different profiles depending on the frequency and intensity of their participation: novices, returners, repeaters and stalwarts. Verlhust and Walgrave (2009) also studied the differences between firsttimers and stalwarts, testing a series of hypotheses to explain the differences between them. In a more recent work, Rüdig and Karyotis (2013) found new 
participants to be more similar to the general population than they are to established protesters. Taking into account the findings of the three studies, we can conclude, in fact, there are significant differences among participants, especially considering their history of participation in protest. Regulars participate more in various social and political organisations. They are ideologically situated on the left and they have a worse evaluation of how the system works. They have a more politically defined identity.

In this paper, we use an excellent framework not only to establish if there are differences between occasionals and regulars, but moreover whether those profiles are closer when we consider the country of the protest. That is, are the Occupy occasionals from both countries more similar to each other? Or are protest participants, regardless of frequency of participation, more alike depending on the country in which the protest takes place? Is it the context of the country where the event takes place that creates similarities between participants and their reasons for participating, or is it the fact that they are occasionals or regulars?

\section{Explanations of Collective Action}

As mentioned above, how people interpret the political context in which they are immersed can be decisive in overcoming the barriers of participation and can also define the individual reasons why someone participates. Classic studies of social psychology on the influence of context are very clear examples of how human behaviour is a function of the environment (Zimbardo, 2007; Lewin, 1936). How people perceive and interpret their environment influences their behaviour. If the interpretation of that context is so important, then we must consider these interpretations in order to better understand what has led people to participate in a protest as unique as Occupy.

We shall describe those socio-political and psychological variables that we believe can help us understand how participants interpreted this political context and how these perceptions are crucial to their participation. In what follows we provide explanations for collective action, running from perceptions of the political context (trust in institutions, satisfaction with democracy, political orientation and political values) to psychological motives (anger, efficacy and identity). We relate those variables to the country where the demonstration takes place as well as mobilisation history, thereafter formulating hypotheses to guide our analyses.

The lack of trust in institutions and poor satisfaction with democracy can feed the intention to participate in protest actions (Anderson \& Mendes, 2006; Dalton et al., 2009). Since the system does not respond to the demands of their people, they choose alternatives to change the state of things. Therefore, in this study we asked participants in Occupy demonstrations for their feelings of trust and satisfaction with the system. We understand these levels will be low, but they will be significantly lower among Spanish participants $(\mathrm{H} 1 \mathrm{a})$, due to the worse economic circumstances of that country. Furthermore, we understand these levels will be very poor among regular protesters, mainly due to the disappointment created by a system they have been fighting against repeatedly (Gómez-Román \& Sabucedo, 2014). Occasionals, though disgusted with the system itself, are not as much so as regulars, since they are only sporadically repudiate the mentioned system $(\mathrm{H} 1 \mathrm{~b})$.

Another variable to help us better understand how people interpret this political context is political orientation. How a person identifies on the scale of ideological left/right position is fundamental to interpretations of the environment around them. The political orientation of citizens provides a general framework for understanding context. It can even be understood as a heuristic from which people turn to explain many of the phenomena occurring in the environment. This political orientation provides a clear guide to understanding certain political issues and what position should be taken on these issues (Hooghe \& Keern, 2013). Having defined a political orientation, individuals create particular political attitudes (Nie, Verba, \& 
Petrocik, 1979) and react accordingly. Participants understand that the Occupy movement, as can be understood from its discourse, should be intermediate on the left / right scale, and should not be identified with any ideology. However, per previous literature (Verlhust \& Walgrave, 2009; Saunders et al., 2012), we expect there will be differences in this respect between occasionals and regulars. It has been found protest participation is more common among those who identify with the left (Dalton et al., 2009), so we expect the regulars to be located along this part of the ideological spectrum $(\mathrm{H} 1 \mathrm{c})$.

As commented before, individuals behave based on how they interpret reality. Political values, close to ideological orientation, can also act as a guide for interpreting the environment. There are several classifications and scales for political values (Inglehart, 1990; Alexander, Inglehart, \& Welzel, 2012; Grasso y Giugni, 2013). One such classification proposal, by Heath, Evans and Martin (1994), differentiates between general orientations of an economic left-right scale (related to economic and political equality and government intervention versus free enterprise) on the one hand, and individual liberties or libertarian-authoritarian on the other (items related with freedom of thought, conscience or the right of association and the relationship person-political institutions).

Given the impaired economic situation, we believe the protesters in the Spanish protest will score more highly on the scale of economic values, because they perceive a threat to their basic needs and will therefore maintain more material concerns $(\mathrm{H} 1 \mathrm{~d})$. We also expect differences between occasionals and regulars in both countries. We understand occasionals take to the streets because their quality of life has been threatened and they will be motivated by economic values (especially in Spain). Regular activists, however, are demanding not only an economic change, but also a modification of the system's functioning. This position is more relevant to individual liberties $(\mathrm{H} 1 \mathrm{e})$.

Once we know that the interpretation of political context by participants may impact their reasons for engaging in collective action, we would like to expound the psychological theories that might explain participation in demonstrations. In social psychology, there is some consensus on the existence of three psychosociological explanations for collective action, those being injustice, efficacy and identity (van Zomeren et. al, 2008; van Stekelenburg \& Klandermans, 2010). These three frames, proposed by Gamson (1992), are fundamental in understanding participation, serve to interpret reality, are socially constructed and culturally contextualised, and encourages participation in collective action (Gamson, 1992).

The first frame corresponds to the perception of injustice. When one perceives oneself as not being treated as deserved, or that an experienced situation is unfair, then one would like to do something to change it (Gurr, 1970). It is important to note that the situation does not always have to be objectively unjust. It must be perceived subjectively as unfair (Kelly \& Breinlinger, 1996). Moreover, if one considers oneself to be poor, but finds an acceptable justification for one's poverty, even if the situation actually is objectively unfair, one will not perceive it as such and will do nothing to change it. Mobilised citizens understand themselves to be unfairly treated and so have decided it is time to act. This injustice frame has a cognitive component, grievances, and an emotional one, anger. According to a meta- analysis by van Zomeren, et al. (2008), the component to best explain collective action is anger. Accordingly, we expect participants in both countries to show high levels of anger, but because the grievance situation in Spain is worse, these levels should be higher there $(\mathrm{H} 2 \mathrm{a})$. For occasionals and regulars, we expect, given the regulars have been participating in the past in similar actions, allowing them to more quickly access a sense of grievance (Tversky and Kahneman, 1981), so that is why we expect them to be angrier $(\mathrm{H} 2 \mathrm{~b})$.

Another frame proposed by Gamson is the efficacy frame. People would not go to the streets to protest if they did not believe they could get something out of it. 
Protesters do cost-benefit calculation for participation (Klandermans, 1984). If individuals think fatalistically, e.g., "Nothing I do can change things", or "It is not in my power to do anything", they will not participate. But when they believe that through joint effort, the group will be able to respond to relevant events, overcome obstacles and achieve collective intermediate goals, they will have sufficient reason to join the mobilisation (Hornsey, et al., 2006). Accordingly, participants in both countries are expected to show feelings of efficacy in some way, but because the Occupy movement had already been successful in Spain and Wall Street at the time it took hold in the UK, we expect the anticipation of success to be greater among British respondents $(\mathrm{H} 2 \mathrm{c})$. Regarding occasionals and regulars, as the regulars have previous experience of successful participation, we expect regulars will be more optimistic than occasionals in consideration of protest as effective $(\mathrm{H} 2 \mathrm{~d})$.

The third collective action model frame that Gamson suggested is the identity frame. Protest participation requires a strong sense of collective identification with the group for fighting collectively against a common disadvantage (Simon et al., 1998). This shared feeling can provoke the necessity to act jointly against the same problem (Sabucedo, Durán, \& Alzate, 2010). According to Stürmer and Simon (2004), when people identify themselves with a group and assume that the adverse condition is motivated by an intergroup power conflict, it becomes what is called politicised identity. The more people identify with a group, the more they are inclined to protest on behalf of that group (Reicher, 1996). According to this framework, the sense of identification should be present among the participants of Spain and the UK, although in the former, given the political situation is worse and as they may feel more aggrieved by the out-group, they potentially would be showing more identification $(\mathrm{H} 2 \mathrm{e})$. In the case of mobilisation history, being a regular implies having been in previous situations where they shared experiences with other participants, so this identification should be stronger among regulars, although certainly not absent in occasionals ( $\mathrm{H} 2 \mathrm{f})$.

If we base our ideas on the precepts above, the principal objectives of the investigation are as follows. First, we shall examine whether there are differences between the different motivations for participation in Occupy participants in Spain and the UK. It is expected that the motives will differ in intensity between both countries. Second, we shall examine whether there are differences in the motives for participation between occasionals and regulars. It is expected that regulars will score more highly in motives determining participation in collective action. Third, we shall try to ascertain whether the interaction between the location and mobilisation history produces changes in the motivations for these protesters to participate. It is expected that there will be stronger motives for participation among regulars, especially in Spain, and that their perceptions of the political context will have been affected, given that they are experiencing a worse economic scenario.

\section{Method}

\section{Participants and procedure}

Our data on participants in protests self-styled by the movement as Occupy were collected in Spain and the UK in 2011, following the methodology suggested by the collaborative European research project Caught in the Act of Protest: Contextualising Contestation. For further information we recommend van Stekelenburg, Walgrave, Klandermans, \& Verlhust (2012).

Respondents completed questionnaires-so-called protest-surveys-distributed during the demonstration ( $n=500-1000)$ - to be returned to the university using prestamped envelopes. The response rate for the demonstrations fluctuated between 25 and 35 per cent. All questionnaires and procedures are standardised. In order to control for response biases we also conducted short (2-3 minutes) interviews 
with a subsample of the respondents $(n=100-200)$ comprising questions identical to those in the printed questionnaire. By comparing the face-to-face interviewees response to the identical questions in the returned questionnaires we can estimate the response bias. On average, somewhat older and more highly educated demonstrators were more likely to return the questionnaire. This non-response did not result in biased findings.

As for the sampling of participants, we designed a sampling strategy such that each participant had the same likelihood of being selected. Demonstrations were covered by a team consisting of 3-4 pointers, and 12-15 interviewers. Each pointer had a team of 4-5 interviewers. The pointers selected the interviewees, while interviewers conducted the interviews and handed out questionnaires. Separating these two roles appeared to be crucial in preventing sampling biases (Walgrave \& Verhulst, 2011). As interviewers tend to select people they believe to be willing to cooperate, they often end up producing biased samples. Interview teams started at different points of the procession and worked towards each other, approaching every $n$-th person in every n-th row. The result was samples we believe to be representative of the demonstrators present.

Our final sample consists of 175 participants: 122 in Spain (55.8 per cent male with a mean age of $40, S D=14.23)$; and 53 in the UK (61.5 per cent male with a mean age of $40, S D=15.31)$. There were no differences among participants in terms of socio-economic class or educational level.

\section{Design}

In this study we propose a $2 \times 2$ factorial design (country where the protest was held: Spain vs. The UK; and participant profile: occasional vs. regulars).

\section{Instruments}

The participants responded to a questionnaire, which included the following variables:

\section{Independent variables}

\section{Place of demonstration: The UK or Spain}

Occasional vs. Regular. We separated participants by taking into account their frequency of participation. They were to answer the following questions: "How many times have you taken part in a demonstration in the past? Ever?" and "In the past twelve months?" There were 5 possible answers: "Never", " 1 to 5", "6 to 10 ", " 11 to 20 " and "more than 20 times". Occasional are those ones who answered 1-5 in the item "ever" and never or 1-5 in "the past 12 months". Regulars are those who answered more than 21 "ever" and more than 6 "in the past 12 months".

\section{Dependent variables}

Most questions were set out on a Likert scale with 5 possible answers ranging from 1 (not at all) to 5 (very much). Those cases where a different measure was used are indicated.

Anger. This was measured with the question, "To what extent do you feel anger when you consider the current economic crisis?"

Efficacy. This was measured from the following statements: "Organized groups of citizens can have a lot of impact on public policies in this country" and "If citizens from different countries join forces, they can have a lot of impact on international politics." $(\alpha=.71)$

Collective identity. This was measured with the following questions: "To what extent do you identify with the other people present at the demonstration?", "To 
what extent do you identify with any organisation staging the demonstration?" ( $\alpha=$ .58)

Satisfaction with democracy. The participants had to answer the question, "In general, how satisfied or dissatisfied are you with the functioning of democracy in your country?" where 0 was not at all satisfied and 10 was very satisfied.

Political trust. Participants were given a list of institutions (National government, National parliament, Political parties, Trade Unions, Judicial system and European Union) and were asked to indicate how much trust they had in them. $(\alpha=.81)$

Left/right placement: The participants had to answer the question, "In politics people sometimes talk of 'left' and 'right'. Where would you place yourself on this scale, where 0 means the left and 10 means the right?"

Political values: We asked participants to what extent they agree or disagree with the following statements; for the economic left-right values we used the following: "Government should redistribute income from the better off to those who are less well off", "Even the most important public services and industries are best left to private enterprise" (reversed coded). ( $\alpha=.54)$. Authoritarian/libertarian values were measured with the items: "Children should be taught to obey authority" (reverse coded), and "People from other countries should be allowed to come to my country and live here permanently if they want to." ( $\alpha=.53)$.

\section{Results}

First, we present data showing the distribution of occasionals and regulars in both countries (Table I). Second, we present the MANOVA with country of demonstration (Spain vs. the UK) and mobilisation history (occasional vs. regulars) as fixed factors; and anger, efficacy, identity, and perception of political context as dependent variables (Table II).

Table I. Distribution of respondents according to their mobilisation history and country

\begin{tabular}{c|ccc}
\hline & Spain & UK & Total \\
\hline Occasional & $64(52.5 \%)$ & $32(60.4 \%)$ & $96(54.9 \%)$ \\
Regular & $58(47.5 \%)$ & $21(39.6 \%)$ & $79(45.1 \%)$ \\
Total & 122 & 53 & 175 \\
\hline
\end{tabular}

As expected, Occupy demonstrations attract more occasionals (54.9 per cent) and fewer regulars (45.1 per cent), in both countries. These data are relevant because they show how new organisations can serve to channel discontent in times of economic crisis and political disaffection, mobilising a great number of sporadic participants.

The high number of regular protesters reported in the Spanish case compared to the British data must be also noted (47.5 vs. 39.6 per cent). This is related to the high number of protests taking place in Spain every year (Jiménez, 2011) and the high number of people who acknowledge to participating frequently in demonstrations (ESS, 2012), confirming once again that protest is one of the most representative forms of collective action in Spain.

Although we do not have large numbers and the sample is unbalanced, we must highlight the relevance of these data, especially in Spain's Occupy, the first demonstration of the movement, and as such ours are unique data. 
Table II. MANOVA analysis comparing country and mobilisation history

\begin{tabular}{|c|c|c|c|c|c|c|c|c|}
\hline FACTOR & DVS & \multicolumn{2}{|c|}{ Factors } & M & SD & $\mathrm{F}$ & Sig & $\eta^{2}$ \\
\hline \multirow{4}{*}{ Country } & \multirow{2}{*}{$\begin{array}{c}\text { Trust in } \\
\text { Institutions }\end{array}$} & \multicolumn{2}{|c|}{ Spain } & 1.92 & 0.53 & \multirow{2}{*}{$11.26_{(1,175)}$} & \multirow{2}{*}{$.001^{* * *}$} & \multirow{2}{*}{.06} \\
\hline & & \multicolumn{2}{|c|}{ UK } & 2.31 & 0.75 & & & \\
\hline & \multirow{2}{*}{$\begin{array}{l}\text { Libertarian } \\
\text { Values }\end{array}$} & \multicolumn{2}{|c|}{ Spain } & 3.57 & 0.78 & \multirow{2}{*}{$4.19_{(1,175)}$} & \multirow{2}{*}{$.04^{*}$} & \multirow{2}{*}{.02} \\
\hline & & \multicolumn{2}{|c|}{ UK } & 3.77 & 0.99 & & & \\
\hline \multirow{16}{*}{$\begin{array}{l}\text { Occasionals vs. } \\
\text { Regulars }\end{array}$} & \multirow{2}{*}{ Anger } & \multicolumn{2}{|c|}{ Occasionals } & 4.29 & 0.77 & \multirow{2}{*}{$5.06_{(1,175)}$} & \multirow{2}{*}{$.03^{*}$} & \multirow{2}{*}{.03} \\
\hline & & \multicolumn{2}{|c|}{ Regulars } & 4.46 & 0.87 & & & \\
\hline & \multirow{2}{*}{ Identity } & \multirow{2}{*}{\multicolumn{2}{|c|}{$\begin{array}{c}\text { Occasionals } \\
\text { Regulars }\end{array}$}} & 3.76 & 0.72 & \multirow{2}{*}{$14.59_{(1,175)}$} & \multirow{2}{*}{$.001^{* \star *}$} & \multirow{2}{*}{.08} \\
\hline & & & & 4.06 & 0.66 & & & \\
\hline & \multirow{2}{*}{ Efficacy } & \multirow{2}{*}{\multicolumn{2}{|c|}{$\begin{array}{c}\text { Occasionals } \\
\text { Regulars }\end{array}$}} & 3.99 & 0.75 & & ค०२** & 05 \\
\hline & & & & 4.26 & 0.69 & y.59 $(1,175)$ & $.002^{n}$ & .05 \\
\hline & Trust in & & onals & 2.12 & 0.66 & & & \\
\hline & Institutions & & lars & 1.94 & 0.59 & & & \\
\hline & $\begin{array}{c}\text { Satisfaction } \\
\text { with }\end{array}$ & & onals & 2.01 & 1.03 & 6.79 & 01 ** & 04 \\
\hline & Democracy & & lars & 1.70 & 0.88 & & & \\
\hline & I eft/riaht & & onals & 2.96 & 1.67 & 5355 & $001^{* * *}$ & 24 \\
\hline & Lent/ngn & & lars & 1.02 & 1.25 & 53.Jつ(1, 175) & .001 & .24 \\
\hline & & & onals & 4.08 & 0.76 & & & \\
\hline & $\begin{array}{l}\text { Economic } \\
\text { Values }\end{array}$ & & lars & 4.79 & 0.41 & $45.14(1,175)$ & $.001^{\pi x x}$ & .21 \\
\hline & Libertarian & & onals & 3.29 & 0.82 & & & \\
\hline & Values & & lars & 4.06 & 0.69 & $(1,1 / 5)$ & .001 & .10 \\
\hline & & Spain & $\begin{array}{c}\text { Occasion } \\
\text { als } \\
\end{array}$ & 4.30 & 0.66 & & & \\
\hline & Angor & & Regulars & 4.33 & 0.96 & & 04 * & ? \\
\hline & Anigel & UK & $\begin{array}{c}\text { Occasion } \\
\text { als }\end{array}$ & 4.28 & 0.96 & $4 . \cup \mathcal{Y}(1,175)$ & .04 & .02 \\
\hline & & & Regulars & 4.86 & 0.36 & & & \\
\hline & & Spain & $\begin{array}{c}\text { Occasion } \\
\text { als }\end{array}$ & 3.89 & 0.62 & & & \\
\hline Country & & & Regulars & 3.97 & 0.63 & & & \\
\hline $\begin{array}{c}x \\
\text { Mobilisation } \\
\text { History }\end{array}$ & Identity & UK & $\begin{array}{c}\text { Occasion } \\
\text { als }\end{array}$ & 3.5 & 0.85 & $9.52(1,175)$ & $.002^{\pi \times}$ & .05 \\
\hline & & & Regulars & 4.28 & 0.70 & & & \\
\hline & & Spain & $\begin{array}{c}\text { Occasion } \\
\text { als }\end{array}$ & 1.91 & .051 & & & \\
\hline & Trust in & & Regulars & 1.92 & 0.56 & $80-2>$ & 005 & 04 \\
\hline & Institutions & UK & $\begin{array}{c}\text { Occasion } \\
\text { als }\end{array}$ & 2.53 & 0.73 & $0.00(1,1 / 5)$ & .000 & .04 \\
\hline & & & Regulars & 1.98 & 0.66 & & & \\
\hline
\end{tabular}

Per the results observed in the Manova analysis (table II), in the case of the variable "country", there are significant differences between Spain and the UK in Trust in institutions $\left(F_{[1,175]}=11.26 ; p=.001\right)$ and libertarian values $\left(F_{[1,175]}=\right.$ $4.19 ; p=.04)$, where the results are higher in the UK, partially confirming hypothesis H1a.

With regard to the variable "mobilisation history" we can see in table II that there are significant differences among occasional and regulars in all the variables under study. Thus, as expected, regulars of both countries are angrier $\left(F_{[1,175]}=10.69 p\right.$ $=.001)(\mathrm{H} 2 \mathrm{~b})$, identified more with the organisation and participants $\left(F_{[1,175]}=\right.$ $17.41 ; p=.001)(H 2 f)$, and perceived themselves as efficacious $\left(F_{[1,175]}=10.05 ; p\right.$ 
$=.002)(\mathrm{H} 2 \mathrm{~d})$, however trust less in institutions $\left(\mathrm{F}_{[1,175]}=7.30 ; p=.008\right)$ and are less satisfied with democracy $\left(F_{[1,175]}=6.79 ; p=.01\right)(\mathrm{H} 1 \mathrm{~b})$. They are located further to the left on the ideological spectrum $\left(F_{[1,175]}=53.55 ; p=.001\right)(\mathrm{H} 1 \mathrm{c})$ and show higher scores in libertarian $\left(F_{[1,175]}=37.94 ; p=.001\right)$ and left-economic values $\left(F_{[1,175]}=45.14 ; p=.001\right)(\mathrm{H} 1 \mathrm{e})$.

We can see that interaction between both independent variables exists and the results are significant for the dependent variables: anger $\left(F_{[1,175]}=4.09 ; p=.04\right)$, identity $\left(\mathrm{F}_{[1,175]}=9.52 ; \mathrm{p}=.002\right)$, and trust $\left(\mathrm{F}_{[1,175]}=8.08 ; \mathrm{p}=.005\right)$.

Figures 1 to 3 show those dependent variables in which there is significant interaction between country and mobilisation history.

Figure 1. Anger

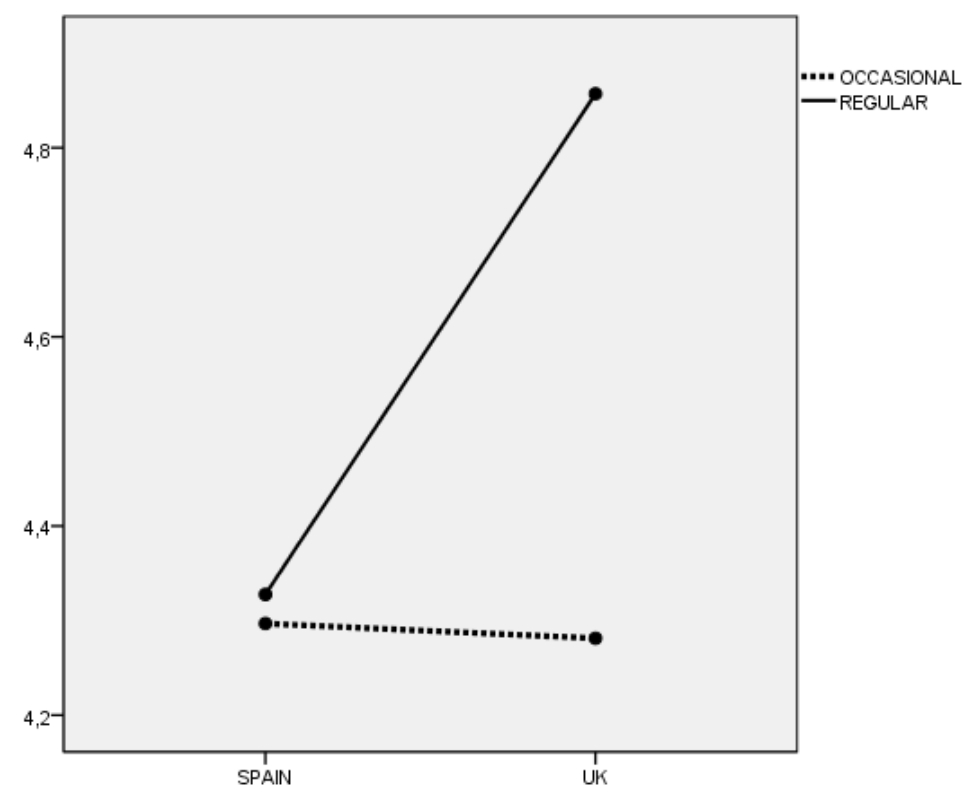

Differences between regulars and occasionals are very clear in terms of anger in the UK, where regulars are angrier. Even more, regulars in the UK are the angriest of the four groups. Contrarily, in Spain, regulars and occasionals share similar levels of anger, very high in both cases, but lower than average British respondents. 
Figure 2. Identity

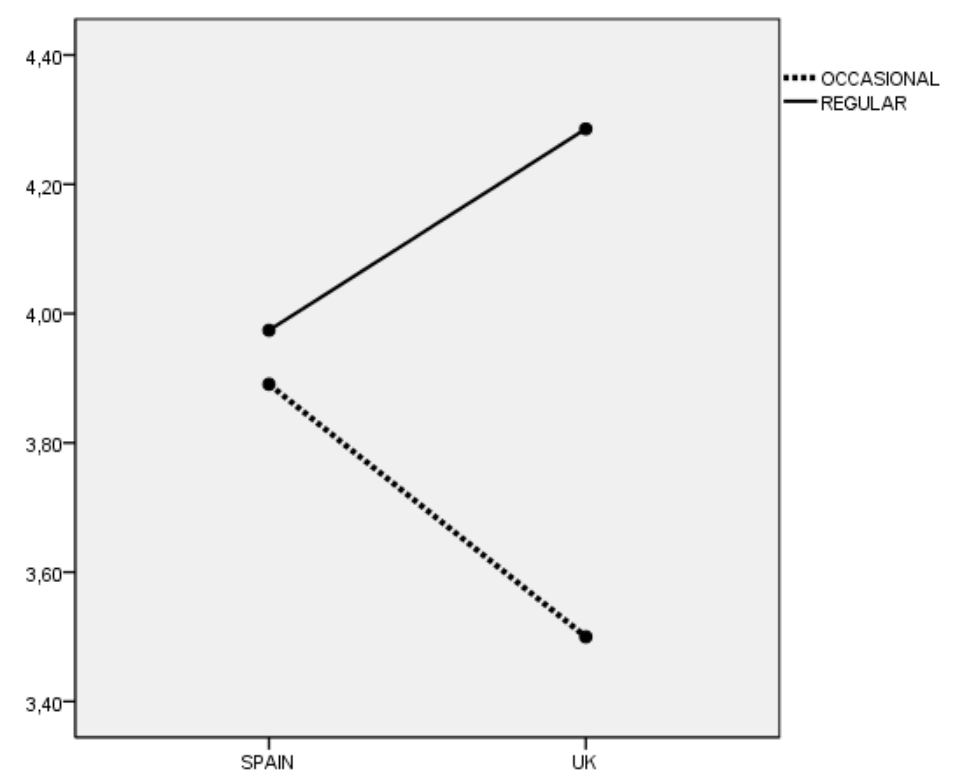

As predicted, levels of identity are high in both countries and both profiles, but contrary to the expected, identity is higher among English regulars. Similarities between participants are very interesting in the case of Spain, where both occasionals and regulars are similarly identified with participants and the organisation.

Figure 3. Trust in Institutions

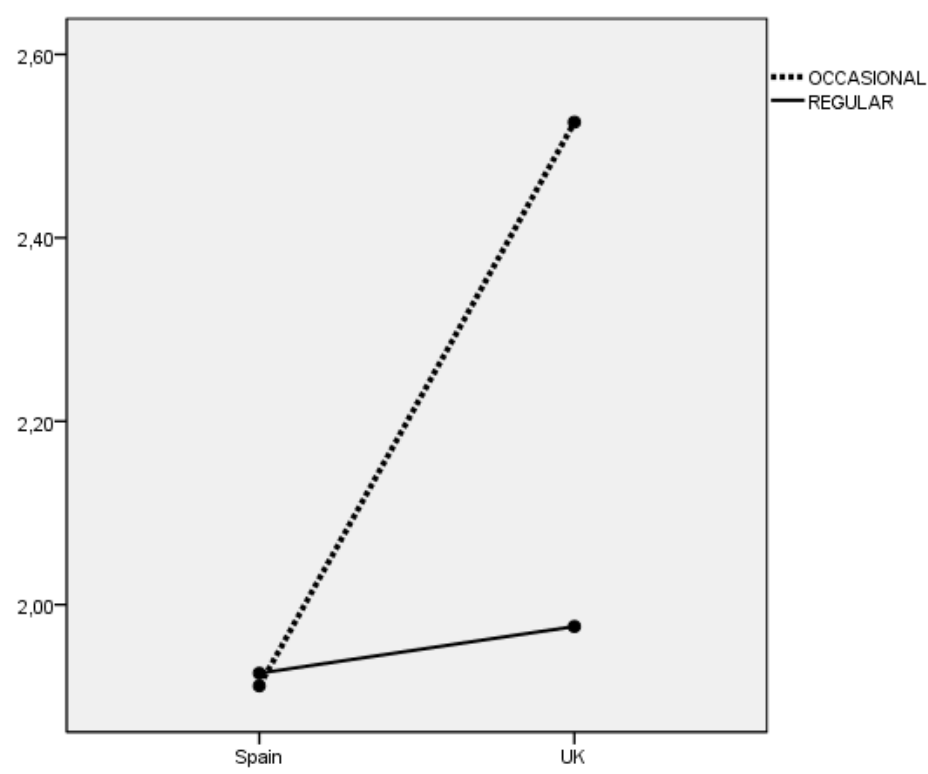


In Figure 3, we can see again the curious effect among Spanish participants, where differences among regulars and occasionals are minimal. British occasionals are the most trustful but the four groups score quite low.

In short, we could extract a general idea from Figures 1 to 3 , which is the similarity among Spanish participants in the Occupy protest. Contrary to what is seen in the UK, where the disparities between occasionals and regulars are notable, in Spain, for both occasional and regular, scores on the variables studied are very similar.

Apart from these significant differences, the groups show important similarities in key variables for political mobilisation. This shows that these variables are important in the context of political protest. Having said that, it is also worth noting that the trend of the results in most cases was in line with our hypotheses. Thus, for instance, regulars were angrier and, more than occasionals, perceived themselves as efficacious. They identified the strongest with the organisation and other participants and hold stronger political values. The results for trust in institutions are notable, where the worse economic situation in Spain makes regulars and occasionals show similarly low results.

\section{Discussion}

In this study, we analysed the motivations of demonstrators in Spain and the UK to participate in Occupy mobilisation. The objective was to compare and examine if the country where the demonstration takes place and the mobilisation history (being an occasional or a regular), changed the motives for participation.

First, we shall discuss what happens to motives when the country is taken into account. As in the case of Walgrave and Rucht's work (2010), those motives determining participation varied depending on this contextual variation. The results indicate that there are significant differences between Spain and the UK, specifically in two of the variables under study: trust in institutions and libertarian values. As predicted in our hypothesis, Spain's worse political and economic context evokes differences in how this context is perceived. This is critical to determine participation. Thus, the Spanish protesters displayed very poor results in trust, while it is true that in the UK the results were also very low. As for libertarian values, and quite related to the relationship of person to institution, it is once again the British demonstrators who score more highly. The interpretation of the crisis situation seems to be what motivates participants in Spain. The disenchantment with austerity policies and the many cases of corruption have taken their toll on how citizens perceive government institutions and its relationship with them. The Indignados movement in Spain has been critical, as it has brought together discontent and political disaffection, challenging the dominant discourse (Moscovici, 1979), creating new frames about reality and introducing new issues in the public agenda. This has allowed them to attract occasional participants to their cause, which explains the high number of participants with this profile in Occupy demonstrations.

Second, we would like to mention the results obtained taking into account the mobilisation history. As can be seen in the data, we found significant differences among occasionals and regulars. As expected, regulars are angrier, identify more with participants and the organisation and they consider themselves more efficacious. They are more disappointed with institutions and democracy, scoring quite low in trust and satisfaction. Despite the Occupy claim, "We are not on the left or right" (Democracia Real Ya, 2014), regular participants, as documented with activists in other studies on protest (Dalton et al., 2009) are more leftist. They score more highly in political values, both economic-left and libertarian. That is to say, those people defending justice in the distribution of wealth will be mobilised to obtain those objectives, demanding not only an economic change but that of operation of the system itself. For this reason they also show higher results in 
those values associated with a change in the relationship between person and political institution (Alexander et al., 2012; Grasso y Giugni, 2013; Inglehart, 1990).

Third, we wanted to examine whether an interaction existed between country and mobilisation history, and how this affected the motives to participate. This interaction is significant for three dependent variables: anger, identity and trust in institutions. Before analysing every interaction individually, we wanted to emphasise the fact that although the Indignados/Occupy demonstration in Spain was able to attract a wide variety of people (fundamentally due to the organisational characteristics and objectives), both occasionals and regulars have a similar emphasis in the motives to participate. This result can be explained by the novelty of the movement and its capacity to create an inclusive identity capable of attracting a varied profile of people.

The Indignados/Occupy movement created an interpretive scheme of reality capable of collecting the political disenchantment of citizens, transforming into the outrage expressed in that mobilisation. For this reason, the levels of anger are high in both countries. As the Occupy movement based its claims on public outrage, it is therefore not surprising that participants score highly in this variable. Scores in the four groups were very high, always above 4 , on a scale of 5 points. Yet, it is also worth noting that the trend of the results regarding the history of mobilisation roughly matches our hypothesis. As such, the regulars express more anger in both countries; however, and contrary to expectations, British demonstrators scored more highly on this variable. This can be explained by the temporary difference between the two movements. The UK's Occupy started later, and British respondents were able to monitor its worldwide evolution, from initial euphoria to the subsequent apathy shown by institutions, which could explain the higher anger score among British regulars.

This also could explain the differences found in identity results. When Occupy emerged in Spain, it was the very first time the term was mentioned. The novelty and freshness of the movement were initially very inclusive, which made both occasionals and regulars feel identified to the same extent, hence the similarity in scores of both Spanish profiles. However, as the movement grew and gained international recognition, their image took a more defined drawing, which reduced the initially wide, blurred identity of the movement. When it erupted in the UK, both international media and governments had been responsible for disseminating and redefining the identity of the movement itself. And even though the scores of participants in the UK are high, both for occasional and regular, those with more experience in mobilisations seem to identify more with the Occupy movement, with the British regulars being those who obtained higher results in this variable.

Lastly, regulars in both countries show lower values in trust in institutions. The most interesting finding, however, is with occasionals. As predicted, the worse political and economical context makes results of distrust more similar to regulars in the Spanish case. So both hypotheses are true: the negative perception of context and the repeated struggle against the system itself are crucial to the interpretation of the context and the different reasons for participation. These results are consistent with classical theories of social psychology. As Lewin pointed out (1936), people react to the context. Socially constructed perceptions produce changes in the way people react to that context, in this case through collective action.

To conclude, it is important to recognise certain limitations to our study. Our methodology allowed us to study real participants at demonstrations, which forces us to adapt our method to these particular circumstances. While it is true that the Occupy movement has been named so because of their camping in city squares, the data in Spain were collected in the previous demonstration leading to the camp protest in Puerta del Sol. This can produce some bias about the commitment and participation of the surveyed protesters. In the British case we certainly know they 
camped, while in Spain the Indignados may or may not have ended up in camp when the demonstration finished. This has also produced differences in the amount of participants for the study: 122 in the Spanish demonstration, and only 53 in the English protest. Even following the same collecting procedure for our data, there were more people protesting at the demonstration in Spain than in London, ergo more respondents to our questions, more people to approach, thus our unbalanced sample. Despite this limitation, we believe the strength of these data lie in the fact that they allow us to compare real participants in collective action. However, we should be cautious with the importance we give to these results. The real value of these findings will become apparent when compared with other studies - those using both the same design models and different ones - in order to overcome aforementioned and unforeseen limitations.

Finally, we would like to stress here the importance of taking into account the history of mobilisation. As mentioned at the beginning of this work, cycles of protest encourage people to engage in collective action. Some will remain occasionals because they will stop protesting as soon as their demand is met, while others will become activists (regular participants), because they will value their experience. Moreover, we cannot forget that activists will be critical for the continuity of such movements.

The results obtained in this study allow us, therefore, to conclude that the interpretation of the context where people are involved is crucial to determining their participation. Those reasons also vary depending on mobilisation history. Social movements' organisations need to take this information into consideration when they create the frames for participation. They need to define which profile of participant they want to attract to emphasise certain aspects of their speech. This is crucial especially in attracting occasional participants with potential for regular activism in that movement.

It is also important to highlight that the appearance of the Occupy movement has substantially changed the dynamics of protest. While it is true this movement followed the dynamics of most protest groups--criticising the government and organising demonstrations against the ruling of the state--its main identity was opposition to the forces of the hegemonic right and left, and questioning the economic and political system as a whole. Governments must consider how important it is to learn from past experiences and remain open to new ways of conceptualising politics. The public sphere cannot be underestimated because this form of action has changed the nature of contemporary political action. There are a variety of Occupy-related collectives continuing to organise (Howard \& PrattBoyden, 2013). Even in Spain, new political parties have risen after these protests, so understanding their participants' motivations can help in negotiating and reaching agreements in the new way of doing politics. As participants posit in their mottos: "From the streets to the Parliament, looking for more direct democracy" (Democracia Real Ya, 2014), governments should take into consideration the new political actor when making decisions.

\section{References}

Alexander, Amy C., Ronald Inglehart, and Christian Welzel (2012) 'Measuring effective democracy: A defense', International Political Science Review 33(1): 4162.

Anderson, Chistopher J., and Silvia M. Mendes (2006) 'Learning to lose: Election outcomes, democratic experience and political protest potential', British Journal of Political Science 36(1): 91-111.

Anduiza, Eva, Camilo Cristancho, and José M. Sabucedo (2013) 'Mobilization through online social networks: The political protest of the Indignados in Spain' Information, Communication \& Society, 17(6): 750-764. 
Biggs, Michael (2014) 'Has protest increased since the 1970s? How a survey question can construct a spurious trend' The British Journal of Sociology 66(1): 142-161.

Costanza-Chock, Sasha (2012) 'Mic check! Media cultures and the Occupy movement' Social Movement Studies 11(3-4): 375-385.

Dalton, Russell, Alix van Sickle, and Steven Weldon (2009) 'The individualinstitutional nexus of protest behavior' British Journal of Political Science 40(1): 5173.

Democracia Real Ya! (2014). Manifiesto. Retrieved from http://www.democraciarealya.es/.

European Social Survey (2012): Data file edition 6.2. Norwegian Social Science Data Services. Retrieved from http://ess.nsd.uib.no/, in March, 2012.

Eurostat (2012) Euro-indicators. Retrieved online 2015-02-04 from http://ec.europa.eu/eurostat

Farnsworth, Kevin, and Zoë Irving (2012) 'Varieties of crisis, varieties of austerity: Social policy in challenging times', Journal of Poverty and Social Justice 20(2): 133-147.

Feixa, C. (2013) 'The \#spanishrevolution and Beyond, Fieldsights. Hot spots, cultural anthropology online, Retrieved from http://www.culanth.org/fieldsights/68-the-spanishrevolution-and-beyond on February 14th, 2013.

Gamson, William A. (1992) Talking politics. Cambridge: Cambridge University Press.

Gledhill, Jim (2012) 'Collecting Occupy London: Public collecting institutions and social protest movements in the 21st century' Social Movement Studies 11(3-4): 342-348.

Gómez-Román, Cristina, and José M. Sabucedo (2014) 'The importance of political context: Motives to participate in a protest before and after the labor reform in Spain' International Sociology 29(6): 546-564.

Grasso, Maria, and Marco Giugni (2013) Anti-Austerity Movements: Old Wine in New Vessels? Paper prepared for the XXVII Meeting of the Italian Political Science Association (SISP), 12-14 September, Florence.

Gurr, Ted R. (1970) Why men rebel. Princeton: Princeton University Press.

Halvorsen, Sam (2012) 'Beyond the network? Occupy London and the Global Movement', Social Movement Studies, 11(3-4): 427-433.

Halvorsen, Sam (2015) 'Taking space: Movements of rupture and everyday life in Occupy London', Antipode 47(2). 401-417.

Heath, Anthony, Geoffrey Evans, and Jean Martin (1994) 'The measurement of core beliefs and values: The development of balanced socialist/laissez faire and libertarian/authoritarian scales', British Journal of Political Science 24(1): 115-132.

Hooghe, Marc, and Anna Keern (2013) 'Party membership and closeness and the development of trust in political institutions: An analysis of the European Social Survey, 2002-2010' Party Politics, 21(6): 944-956.

Hornsey, Matthew J., Leda Blackwood, Winnifred Louis, Kelly Fielding, Ken Mavor, Thomas Morton, Anne O'Brien, Karl-Erik Paasonen, Joanne Smith, and Katherine M. White (2006) 'Why do people engage in collective action? Revisiting the role of perceived effectiveness', Journal of Applied Social Psychology 36(7): 1701-1722. 
Howard, Neil, and Keyra Pratt-Boyden (2013) 'Occupy London as pre-figurative political action', Development in Practice 23(5-6): 729-741

Inglehart, Ronald (1990) Culture Shift in Advanced Industrial Society. New Jersey: Princeton University Press.

Instituto Nacional de Estadística (2011) Encuesta de población activa. Retrieved online 2015-02-04 from http://www.ine.es/

Jiménez-Sánchez, Manuel (2011) La normalización de la protesta. El caso de las manifestaciones en España (1980-2008). Madrid: Centro de Investigaciones Sociológicas.

Klandermans, Bert (1984) 'Mobilization and participation: Social-psychological expansions of resource mobilization theory', American Sociological Review, 49(5):

583-600.

Klandermans, Bert, and Jackie Smith (2002) Survey research: A case for comparative designs, in Bert Klandermans, and Suzanne Staggenborg (eds.), Methods of social movement research. Minneapolis: University of Minnesota Press, pp. 3-31.

Klandermans, Bert, Jacquelien van Stekelenburg, Marie-Louise van Damen, Anouk van Leeuwen, and Dunya van Troost (2014). Mobilization without organization: The case of unaffiliated demonstrators. European Sociological Review, 30(6): 702-716.

Kelly, Caroline, and Sara Breinlinger (1996) The social psychology of collective action. Basingstoke, England: Taylor \& Francis.

Langman, Lauren (2013) 'Occupy: A new social movement', Current Sociology 1(4): 510-524.

Lewin, Kurt (1936) Principles of Topological Psychology. Nueva York: McGraw-Hill

Manilov, Marianne (2013) 'Occupy at one year: Growing the roots of a movement', The Sociological Quarterly 54(2): 206-213.

McNally, David (2010) Global Slump: The Economics and Politics of Crisis and Resistance. Oakland, CA: PM Press/Spectre.

Moscovici, Serge (1979) El psicoanálisis, su imagen y su público. Buenos Aires: Huemul S.A.

Nie, Norman H., Sydney Verba, and John R. Petrocik (1979) The changing American voter. Cambridge, MA: Harvard University Press.

Occupy London (2014) Occupy London Statements. Retrieved from http://occupylondon.org.uk/ Pickerill, Jenny, and John Krinsky (2012) 'Why does Occupy matter?', Social Movement Studies 11(3-4): 279-287.

Reicher. Steve D. (1996) 'The Battle of Westminster: Developing the social identity model of crowd behaviour in order to explain the initiation and development of collective conflict', European Journal of Social Psychology 26(1): 115-134.

Rüdig, Wolfgang, and Georgios Karyotis (2013) 'Beyond the usual suspects? New participants in anti-austerity protests in Greece', Mobilization: An International Journal 18(3): 313-330.

Sabucedo, José M., Mar Durán, and Mónica Alzate (2010) 'Identidad colectiva movilizada', Revista de Psicología Socia, 25(2): 189-201.

Saunders, Clare, Maria Grasso Cristiana Olcese, Emily Rainsford, and Christopher Rootes (2012) 'Explaining differential protest participation: Novices, returners, repeaters, and stalwarts', Mobilization: An International Journal 17(3): 263-280. 
Simon, Bernd, Stegan Stürmer, Michael Loewy, Ulrike Weber, Peter Freytag, Corinna Habig, Claudia Kampmeier, and Peter Spahlinger (1998) 'Collective identification and social movement participation', Journal of Personality and Social Psychology 74(3): 646-658.

Stürmer, Stefan, and Bernd Simon (2004) 'Collective action: Towards a dualpathway model, European Review of Social Psychology 15(1): 59-99.

Tarrow, Sidney G. (1991) Struggle, politics, and reform: Collective action, social movements and cycles of protest. Ithaca, NY: Center for International Studies, Cornell University.

Tejerina, Benjamín, Ignacia Perugorría, Tova Benski, and Lauren Langman (2013) 'From indignation to occupation: A new wave of global movilization', Current Sociology 64(1): 377-392.

Thomas, Emma F., and Winnifred R. Louis (2013) 'Doing democracy: The social psychological mobilization and consequences of collective action', Social Issues and Policy Review 7(1); 173-200

Tilly, Charles (1986) The contentious French. Four centuries of popular struggle. Cambridge: Harvard University Press.

Tversky, Amos, and Daniel Kahneman (1981) The framing of decisions and the psychology of choice, Science 211(4481); 455-458.

van Stekelenburg, J., and Bert Klandermans (2010) 'Individuals in movements: A social psychology of contention' in Bert Klandermans and Conny M. Roggeband (Eds.), The handbook of social movements across disciplines. New York: Springer, pp. 157-204.

van Stekelenburg, Jacquelien (2012) 'The occupy movement: Product of this time' Development 55(2): 224-231.

van Stelekelenburg, Jacquelien, Stefaan Walgrave, Bert Klandermans, and Joris Verlhust (2012) 'Contextualizing contestation: Framework, design, and data', Mobilization: An International Journal 17(3): 249-262.

van Zomeren, Martijn, Tom Postmes, and Russell Spears (2008) 'Toward an integrative social identity model of collective action: A quantitative research synthesis of three socio-psyhological perspectives' Psychological Bulletin 134(4); 353-372.

Verhulst, Joris, and Stefaan Walgrave (2009) 'The first time is the hardest? A cross-national and cross-issue comparison of first-time protest participants', Political Behavior 31(3); 455-484.

Walgrave, Stefaan, and Dieter Rucht (2010) The world says no to war. Demonstrations against the war on Angerq. Minneapolis, MN: University Of Minnesota Press.

Walgrave, Stefaan, and Joris Verhulst (2011) 'Selection and response bias in Protest Surveys', Mobilization: An International Quarterly 16(2); 203-222.

Zimbardo, Philip G. (2007) The Lucifer effect. Understanding how good people turn evil. New York: Random House. 